Note

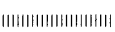

\section{Evaluation of an Electrostatically Forced Fogging by Immunological Analysis of Chlorothalonil Deposits}

\author{
Yoshiyuki TAKAHASHI, Akiko HAYASHI, ${ }^{*}$ \\ Yutaka WADA, Toru UMEZU** \\ and Yoichi NAMAE* \\ Research Institute of Japan Plant Protection Association, \\ Kessoku, Ushiku 300-12, Japan \\ *Pesticide Research Department, Zen-Noh Agricultural Techni- \\ cal Center, Higashi-Yahata, Hiratsuka 254, Japan \\ **Business Development Department, Sceti Co., Ltd., \\ Minato-ku, Tokyo 107, Japan
}

(Received February 16, 1996 ; Accepted May 29, 1996)

\section{INTRODUCTION}

A non-heat type (NH) fogging is one of low volume applications of pesticides for greenhouse cultures. It has advantages such as labor saving and operator protection against pesticide exposure during pesticide applications. However, deposit efficiency to the undersides of leaves, i.e., facing the ground, is generally very low because droplets of the fog may adhere mainly to horizontal upper surfaces due to gravity. For improvement of deposition to the undersides of leaves with $\mathrm{NH}$ fogging, an electrostatically forced (EF) fogging has been developed. ${ }^{1)}$ The EF fogging machine has a ring for electric charge at the fog nozzle of a $\mathrm{NH}$ fogging machine, which accumulates electric charges to the droplets of pesticide. The charged droplets will deposit on plant surfaces by coulomb attraction. ${ }^{2)}$

The deposit efficiency of a particular pesticide has been evaluated by counting particles of the pesticide on a glass slide after application ${ }^{3}$ or by determining the pesticide extracted from plants with HPLC, GC or GC-MS.4) For the development and/or improvement of application techniques the pesticide deposits have been primarily measured by using glass slides or papers because these substitutes for plant leaves are easier to handle and more cost-effective. However, it is doubtful whether the deposits on those substitutes are really regarded as representatives of those on leaf surfaces. In a previous study, we demonstrated the usefulness of an immunological analysis of chlorothalonil (TPN), applied by fogging techniques on leaf surfaces of eggplants.5) The results revealed a disappointingly low level of deposit of TPN on the undersides of leaves by EF fogging, although the deposition by EF fogging was slightly better than by $\mathrm{NH}$ fogging.

In this study, the deposit of TPN on glass slides applied by
EF fogging was analysed by both an immunoassay measuring technique and a microscopic observation of TPN particles, and the effectivity of the two techniques was compared. Furthermore, deposits on glass slides and on leaf surfaces of cucumber plants after the application of TPN with both EF and $\mathrm{NH}$ foggings were analysed by the immunoassay technique to evaluate the efficacy of the EF fogging technique.

\section{MATERIALS AND METHODS}

\section{Fog Applications}

Experiment 1: Six locations (a)-(f) (Fig. 1A) were selected in a $100 \mathrm{~m}^{2}$ greenhouse without plants. A two-ply glass slide was set at $1.5 \mathrm{~m}$ above the ground at each location. An electrostatically forced (EF) fogging machine (KLV90E, Kioritz Corp., Japan) was placed near the central entrance to the greenhouse (Fig. 1A). Thirty milliliters of Daconil ${ }^{\circledR}$ 1000 (TPN 40\% suspension concentrate, SDS Biotech K.K., Japan) diluted in $1 l$ of water was applied to the greenhouse under the conditions of $3 \mathrm{~kg} / \mathrm{cm}^{2}$ of air pressure, $50 \mathrm{ml} / \mathrm{min}$ of pesticide solution discharge and $400 \mathrm{~V}$ of electric charge.

Experiment 2: Two $200 \mathrm{~m}^{2}$ greenhouses containing 256 cucumber plants $(190-200 \mathrm{~cm}$ in height) were used for fog applications. The EF fogging machine and a non-heat type (NH) fogging machine (SLVH-10C, Arimitsu Industry Co., Ltd., Japan) were placed near the central entrance to the greenhouses, respectively. Fifty milliliters of Daconil ${ }^{\circledR} 1000$ diluted in $1 l$ of water was applied in each greenhouse by each
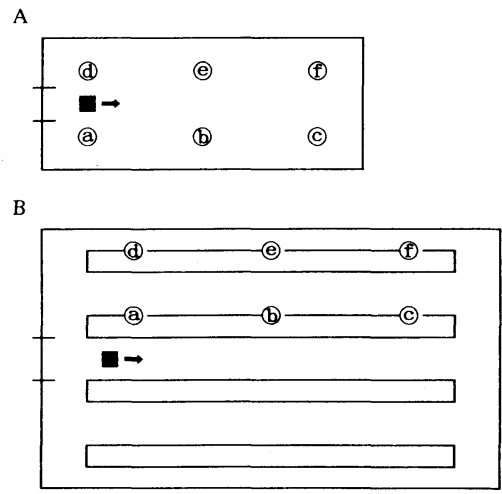

Fig. 1 (A) In Experıment 1, two-ply glass slides were set at $1.5 \mathrm{~m}$ above the ground at six locations (a)-(f)) in a $100 \mathrm{~m}^{2}$ greenhouse without plants for electrostatically forced (EF) fogging.

(B) In Experiment 2, leaf disks were collected from two of four beds of cucumber plants contained in each of two 200 $\mathrm{m}^{2}$ greenhouses. One greenhouse was exposed to EF fogging and one to non-heat type fogging. The leaf disks were collected from six locations (a)-(f) in each greenhouse at $1.2 \mathrm{~m}$ above the ground. Two-ply glass slides were also set near each sampling point at the same height $(1.2 \mathrm{~m})$ as in Experiment 2. $\mathbf{a}$ : fogging machine, $\rightarrow$ : direction of fog stream. 
fogging machine. Six sampling points (a)-(f) were selected in each greenhouse for TPN deposit measurements (Fig. 1B). For exposing only one side of the cucumber leaf surface to TPN, the leaf surfaces at $1.2 \mathrm{~m}$ above the ground were sandwiched by papers both with and without a circular opening of $5.5 \mathrm{~cm}$ in diameter as in the previous study. ${ }^{5)}$ Two-ply glass slides were also set near the each sampling point of the same height.

A day after application of TPN in each experiment, all of the two-ply glass slides were collected from each location in the greenhouses. Leaf disks $(\phi 5 \mathrm{~cm})$ exposed to TPN on either the upper or under the surfaces were also collected from each sampling point in the greenhouses in Experiment 2.

\section{Deposit Index with Microscopic Observation}

Each two-ply glass slide exposed to TPN in Experiment 1 was separated into the upperside and underside. Deposit of TPN particles on both sides was observed by a microscope $(X$ 100) and rated according to the standard deposit index, which graded pesticide deposit on the glass slide from No. 0 (no particle) to No. 8 (tightly concentrated particles), of The Institute of Agricultural Machinery, Bio-oriented Technology Research Advancement Institution.

\section{Extraction of Chlorothalonil}

After determination of the deposit index with microscopic observation, each glass slide with one surface exposed to TPN was put into a $50 \mathrm{ml}$ centrifuge tube with $10 \mathrm{ml}$ of methanol. Approximately $10 \mathrm{ml}$ of extract was collected after shaking each tube vigorously for $1 \mathrm{~min}$ by hand.

Extraction of TPN from each leaf disk was performed by using a polyethylene bag as described previously. ${ }^{5)}$ In Experiment 2, aphids on the undersides of leaves and trichomes on petiole were also collected from each sampling point of (b) in Fig. 1B after TPN application. Each aphid and trichome was put into a microtube with $100 \mu 1$ of methanol for extraction of TPN.

All extracts were stored at $-80^{\circ} \mathrm{C}$ until analyzed.

\section{Immunological Determination and HPLC}

Each extract from the glass slides, leaf disks, aphids and trichomes was analyzed by an immunoassay $\mathrm{kit}^{6)}$ (RaPID Assay kit, Ohmicron Corp., U.S.A.) as described previously. ${ }^{5}$

Five milliliters of extract from each of 24 leaf disks was also analysed by HPLC (LC-9A System, Shimadzu Corp., Japan).

\section{RESULTS AND DISCUSSION}

\section{Reliability of Immunoassay}

The reproducibility of immunoassay ( $n=15,99.6 \%: 88-$ $112 \%)$ and the coefficient of correlation with HPLC $(n=18$, $r=0.961$ ) were similar to those of the previous study. ${ }^{5}$ The consistency of these results puts a high confidence factor on the accuracy of the immunoassay technique.
2. Comparison of Microscopic Observation and Immunoassay Detection of TPN on Glass Slides

The deposits of TPN on each surface of the glass slides by EF fogging were measured by both microscopic observation using the deposit index and immunoassay in Experiment 1. The results are shown in Table 1 . The ratio of deposit on the underside of glass slide to that on the upperside was $53 \%$ by microscopic observation and $57 \%$ by immunoassay. The coefficients of correlation between the two analyses were 0.949 for upperside $(n=6)$ and 0.988 for underside $(n=6)$. Based on the comparison, the results of the two evaluation methods for TPN deposits on glass slides seemed to be significantly coincident.

\section{Comparison of Deposition on Glass Slides and on Cucumber Leaves}

In Experiment 2, TPN was applied to glass slides and cucumber plants using both EF and NH fogging. The average deposits on each surface of the glass slides and cucumber leaves as detected by immunoassay are shown in Table 2. When the deposits of TPN on the uppersides of the glass slides and leaves were compared, the coefficients of correlation between the two surfaces are 0.694 in EF and 0.935 in $\mathrm{NH}$ fogging. On the other hand, coefficients of correlation between the deposits on the underside of the both surfaces are 0.341 in EF and -0.156 in NH fogging. These indicate that the deposition applied by EF fogging on the underside of glass slide is not representative of that on leaf surfaces. Moreover, evaluation with glass slides would lead to overestimation of EF fogging efficiency.

Based on the results shown in Tables 1 and 2, the glass slide as a substitute was unavailable for the evaluation of EF fogging, though it seemed to be available for the NH fogging.

Table 1 Deposit of TPN on glass slides analysed by both deposit index and immunoassay after application by electrostatically forced fogging.

\begin{tabular}{|c|c|c|c|c|}
\hline \multirow{2}{*}{$\begin{array}{l}\text { Sampling } \\
\text { point }\end{array}$} & \multicolumn{2}{|c|}{ Deposit index ${ }^{a)}$} & \multicolumn{2}{|c|}{ Immunoassy $^{\text {b) }}$} \\
\hline & Upperside & Underside & Upperside & Underside \\
\hline $\mathrm{a}$ & 5 & 2 & 6.3 & 2.6 \\
\hline $\mathrm{b}$ & 7 & 5 & 12.3 & 7.3 \\
\hline c & 5 & 1 & 4.6 & 1.5 \\
\hline d & 6 & 3 & 8.0 & 4.5 \\
\hline $\mathrm{e}$ & 8 & 7 & 18.5 & 12.9 \\
\hline $\mathrm{f}$ & 6 & 2 & 5.9 & 2.9 \\
\hline Average & 6.2 & 3.3 & 9.3 & 5.3 \\
\hline $\begin{array}{l}\text { Ratio of } \\
\text { under/upper }\end{array}$ & \multicolumn{2}{|c|}{$53 \%$} & \multicolumn{2}{|c|}{$57 \%$} \\
\hline
\end{tabular}

a) According to the standard deposit index (0-8) by observation with microscope.

b) TPN deposits $(\mu \mathrm{g} / \mathrm{ml})$ determined by immunoassay.

c) Ratio of deposit on the underside of glass slide to that on the upperside. 
Table 2 Comparison of TPN deposits between on glass slides and on leaf disks from cucumber plants.

\begin{tabular}{|c|c|c|c|c|}
\hline \multirow{2}{*}{ Fogginga) } & \multirow{2}{*}{ Sample } & \multicolumn{2}{|c|}{ Average deposit ${ }^{\mathrm{b})}\left(\mu \mathrm{g} / \mathrm{cm}^{2}\right)$} & \multirow{2}{*}{$\begin{array}{c}\text { Ratio }^{\text {c) }} \text { of } \\
\text { under/upper }\end{array}$} \\
\hline & & Upperside & Underside & \\
\hline \multirow{2}{*}{$\mathrm{EF}$} & Glass slide & 2.709 & 1.016 & $37.5 \%$ \\
\hline & Leaf disk & 1.668 & 0.034 & $2.0 \%$ \\
\hline \multirow{2}{*}{ NH } & Glass slide & 1.807 & 0.028 & $1.5 \%$ \\
\hline & Leaf disk & 2.192 & 0.050 & $2.3 \%$ \\
\hline
\end{tabular}

a) $\mathrm{EF}$ : electrostatically forced fogging, $\mathrm{NH}$ : non-heat type fogging.

b) Deposits of six samples were averaged.

c) Ratio of deposit on the underside of glass slide to that on the upperside.

Table 3 TPN deposits on individual aphids collected from the underside of cucumber leaves.

\begin{tabular}{llll}
\hline \multirow{2}{*}{ Aphid } & \multicolumn{2}{c}{ Average deposit (ng/aphid) } & \multirow{2}{*}{ EF/NH } \\
\cline { 2 - 3 } & \multicolumn{1}{c}{ EF fogging } & \multicolumn{1}{c}{ NH fogging } & \\
\hline Adult $^{\text {a) }}$ & $3.20(0.96-8.30)$ & $0.86(0.24-1.90)$ & 3.75 \\
Nymph $^{\text {b) }}$ & 1.05 & 0.28 & 3.72
\end{tabular}

a) Deposits of five individual adult aphids were averaged. The numbers in parentheses indicate minimum and maximum of deposit.

b) Deposits on five nymphs were analysed together, then calculated for one nymph.

\section{Evaluation of Efficacy of Electrostatic Force}

As described above, the effectiveness of the EF fogging observed on the underside of glass slides was not observed on the underside of leaves. However, in EF fogging, the average TPN deposit on individual aphids from the underside of leaf was 3.7 times as high as that by $\mathrm{NH}$ fogging (Table 3). Furthermore, the average deposit of TPN on trichomes of petiole applied by EF fogging was 4.6 times as high as that by $\mathrm{NH}$ fogging (data not shown). These results may indicate that charged droplets in EF fogging are specifically deposited on microstructures on plant surfaces. Thus, an insecticide applied by EF fogging might be expected to be more effective than by NH fogging for controlling insects such as aphids. However, further experiments should be necessary to prove that EF fogging is more effective for different kinds of pesticides or formulation than $\mathrm{NH}$ fogging.

\section{ACKNOWLEDGMENTS}

The authors are indebted to Dr. Donald W. Durandetta, Ohmicron Corporation, for his critical reading of the manuscript.

\section{REFERENCES}

1) T. Ono: Shokubutsu boeki (Plant Prot.) 40, 114 (1986) (in Japanese)

2) G. A. Mathews: Crop Prot. 8, 3 (1989)

3) S. Yoneyama: Shokubutsu boeki (Plant Prot.) 40, 109 (1986) (in Japanese)

4) R. Hiramatsu : Shokubutsu boeki (Plant Prot.) 40, 103 (1986) (in Japanese)

5) Y. Takahashi, A. Hayashi, A. Sakurai, T. Umezu \& Y. Wada: J. Pesticide Sci. 21, 65 (1996)

6) F. M. Rubio, J. A. Itak, A. M. Scutellaro, M. Y. Selisker \& D. P. Herzog : Food Agric. Immunol. 3, 113 (1991)

\section{要 約 \\ Chlorothalonil の付着量の免疫学的分析による静電式常 温煙霧法の評価}

高橋義行，林 明子，和田 豊

梅津 透, 生江洋一

静電式常温 $(\mathrm{EF})$ 煙霧の評価ために, $100 \mathrm{~m}^{2}$ の施設内にスラ イドガラスを葉の代替として設置し, chlorothalonil (TPN) の 下（裏）面への付着率を上（表）面対比で調べた結果，TPN 粒

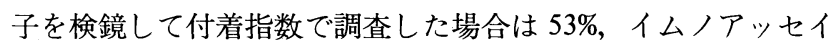
(IA) 法で検定した場合は $57 \%$ であった。ささらに $200 \mathrm{~m}^{2}$ の二つ のキュウリ栽培施設内にスライドガラスを設置して，TPNの EF 煙霧と常温 $(\mathrm{NH})$ 煙霧を行ない，TPN の付着量を IA 法で 分析測定した結果，スライドガラスの下(裏)面における上(表) 面に対する付着率は $\mathrm{EF}$ 煙霧で $37.5 \%$ であり $\mathrm{NH}$ 煙霧 $(1.5 \%)$ 上 りも多量の付着が認められたが，キュウリ葉の裏面付着率はそ れぞれ $2 \%$ と $2.3 \%$ で, $\mathrm{EF}$ 煙霧による付着量の増加は認められ なかった。一方，葉裏に生息するアブラムシおよび葉柄の毛耳 への付着量を両煙霧法で比較した結果， $\mathrm{EF}$ 煙霧による付着量 はそれぞれ NH 煙霧の 3.7 倍および 4.6 倍であり，このアブラ ムシ等への付着量の増加は静電式が殺虫剂の防除効果の向上に 寄与する可能性を示唆している. 